\title{
Growth Hormone Secretory Capacity of Individual Somatotropes in Rats with Chronic Renal Insufficiency
}

\author{
LAWRENCE F. POLETTI, RICHARD J. KRIEG JR., FERNANDO SANTOS,' KAZUHIKO NIIMI, \\ JAMES D. HANNA, AND JAMES C. M. CHAN \\ Departments of Pediatrics [F.S., K.N., J.D.H., J.C.M.C.] and Anatomy [L.F.P., R.J.K.], Medical College of \\ Virginia, Richmond, Virginia 23298
}

\begin{abstract}
Growth failure is a common consequence of chronic renal insufficiency (CRI) in children and may be due to a number of factors. With regard to growth hormone (GH), regulation is often abnormal in CRI patients. The present study investigated the effect of CRI on the GH secretory responsiveness to GH-releasing hormone in individual rat pituitary somatotropes. Male Sprague-Dawley rats underwent a $\%$ nephrectomy to produce CRI. Control rats (SHAM) received sham operations, which included kidney decapsulation but not removal. Two wk later, during a period of stable uremia, serum creatinine [CRI: $1.1 \pm$ $0.08 \mathrm{mg} / \mathrm{dL}(97 \pm 7 \mu \mathrm{mol} / \mathrm{L}) ;$ SHAM: $0.4 \pm 0.04 \mathrm{mg} / \mathrm{dL}$ $(35 \pm 4 \mu \mathrm{mol} / \mathrm{L})]$ and serum urea nitrogen [CRI: $60.7 \pm$ $8.3 \mathrm{mg} / \mathrm{dL}(21.7 \pm 3.0 \mathrm{mmol} / \mathrm{L})$; SHAM: $15.8 \pm 1.2 \mathrm{mg} /$ dL $(5.6 \pm 0.4 \mathrm{mmol} / \mathrm{L})]$ were significantly elevated in the CRI rats $(p<0.0005)$. Weight gain $(p<0.0005)$, length gain $(p<0.0005)$, food intake $(p<0.0005)$, and food efficiency $(p<0.005)$ were all significantly lower in the CRI rats. The GH secretory capacity of individual somatotropes was determined using the reverse hemolytic plaque assay technique. Plaque areas were measured to assess relative amounts of GH secreted. The total number of pituitary cells per rat, the percentage of somatotropes, and the mean plaque areas were similar for the two groups. These findings compare favorably with our in vitro study of $\mathrm{GH}$ responsiveness in perifused rat pituitary cells under conditions of mild uremia. We conclude that the secretory responsiveness of individual somatotropes is not significantly changed under conditions of moderate CRI, and that potential abnormalities in GH secretion are due to factors other than an alteration in the capability of somatotropes to respond to GH-releasing hormone. (Pediatr Res 31: 528-531, 1992)
\end{abstract}

\section{Abbreviations}

CRI, chronic renal insufficiency

GH, growth hormone

GHRH, growth hormone-releasing hormone

CRI in children is frequently complicated by growth failure (1-5). The etiology of this growth failure is complex, and nutritional, metabolic, and hormonal disturbances have been implicated (3, 5-7).

Received August 6, 1991 ; accepted January 10, 1992.

Correspondence: Dr. J. C. M. Chan, Department of Pediatrics, Medical College of Virginia, Box 498, MCV Station, Richmond, Virginia 23298-0498.

I Present address: Seccion de Nefrologia Pediatrica, Hospital Universitario Covadonga, c/Celestino Villamil, Oviedo 33006 Asturias, Spain.
The role played by the GH axis is unclear. Circulating concentrations of $\mathrm{GH}$ have been found to be elevated in patients with CRI $(8-12)$ and in partially nephrectomized animals (13). This may be due in part to inadequate excretion of $\mathrm{GH}$, inasmuch as the kidney is the major site for GH excretion (14). However, some evidence suggests that the elevated concentrations are mainly due to increased GH secretion (12). In addition to high circulating levels of $\mathrm{GH}$, the $\mathrm{GH}$ response to various stimuli (glucose, hypoglycemia, thyrotropin releasing hormone) is abnormal among patients with CRI. Abnormalities include a paradoxical rise in GH with glucose infusion $(8-11,15,16)$ and a lack of GH release with hypoglycemia (16). In one study, a decreased pituitary GH content was observed in uremic rats (17). The involvement of the $\mathrm{GH}$ axis in the etiology of growth failure in CRI may be the basis of improved growth seen in uremic rats $(13,18,19)$ and children $(20-22)$ given high doses of $\mathrm{GH}$.

The current study was undertaken to gain further understanding of the effects of CRI on GH secretion. Using the reverse hemolytic plaque assay technique, the secretory capacity of individual pituitary somatotropes in response to varying concentrations of GHRH was determined in nephrectomized and shamoperated rats.

\section{MATERIALS AND METHODS}

Animals. Male Sprague-Dawley rats were obtained from Charles River Breeding Laboratories (Wilmington, MA) and maintained in individual cages in an environmentally controlled animal facility with a 12-h light, 12-h dark schedule. The temperature was maintained at $21-23^{\circ} \mathrm{C}$. Standard rodent laboratory Chow (Ralson-Purina Co., St. Louis, MO) in powdered form and water were available ad libitum.

Nephrectomy. The experimental protocol was approved by Virginia Commonwealth University's Institutional Animal Care and Use Committee. To produce CRI, the animals $(n=6)$ underwent a two-stage nephrectomy. In the first stage, the right kidney was decapsulated and the upper and lower thirds were removed. In the second stage 1 wk later, the entire left kidney was excised. Sham-operated control rats underwent identical operative procedures up to and including decapsulation of the kidneys. Surgical procedures were performed on rats anesthetized with pentobarbital $(1.25 \mathrm{mg} / 100 \mathrm{~g}$ body weight intraperitoneally) and ketamine $(4.0 \mathrm{mg} / 100 \mathrm{~g}$ body weight intramuscularly).

Measurements. Linear measurements (nose to tail tip) were carried out using a ruler (19). The weights of the rats and the amount of food consumed were determined using an electronic balance (19). Food intake was quantitated every other day as the weight difference between food containers when full and just before refill. Food efficiency was calculated by dividing the weight gained during the 2-wk period after nephrectomy by the total food intake during the same 2-wk period (19). 
Blood was collected after rapid decapitation under anesthesia. Serum creatinine concentrations were determined using a Beckman Creatinine Analyzer II (Beckman Instruments, Inc., Brea, CA). Serum urea nitrogen was determined by electrode using an autoanalyzer (Astra; Beckman Instruments, Inc.).

Reverse hemolytic plaque assay. The reverse hemolytic plaque assay for individual pituitary somatotropes was performed as previously described (23). Briefly, the pituitary glands were removed immediately after decapitation. After separating and discarding the neurointermediate lobe, the anterior pituitary was diced and dispersed using $0.25 \%(0.0025)$ trypsin in $10 \mathrm{~mL}$ minimum essential medium (SMEM, no. 410-1400; Gibco, Grand Island, NY). Dispersion took place during gentle stirring in a siliconized spinner flask (Bellco Glass, Inc., Vineland, NJ) partially submerged in a $37^{\circ} \mathrm{C}$ water bath for $60 \mathrm{~min}$ followed by gentle trituration using a $1.0-\mathrm{mL}$ pipetter (Pipetman; Rainin Instruments, Woburn, MA). The cells were washed and resuspended in SMEM containing $0.1 \%(0.001)$ BSA. A total cell count was performed using a standard hemocytometer. The cell suspension was adjusted to a density of $4 \times 10^{5}$ cells $/ \mathrm{mL}$, and $0.5 \mathrm{~mL}$ of pituitary cells were combined with $0.5 \mathrm{~mL}$ of a $12 \%$ $(0.12)$ suspension of ox erythrocytes (Colorado Serum Co., Denver, $\mathrm{CO}$ ) that had been previously coated with protein-A (Staphylococcus aureus; no. P8143, Sigma Chemical Co., St. Louis, $\mathrm{MO}$ ). The cell mixture was infused into a culture chamber similar to that described by Cunningham and Szenberg (24) constructed on a glass microscope slide previously coated with fresh poly-llysine $(0.2 \mathrm{~g} / \mathrm{L} ; 30$-min coat time) to enhance cell adhesion. After a 60 -min incubation at $37^{\circ} \mathrm{C}$ to allow cell attachment, the culture medium within the chambers was replaced with Dulbecco's Modified Eagle's Medium (DMEM, no. 430-1600; GIBCO Laboratories, St. Lawrence, MA) and all cells that had not attached to the slide were washed out. After another 30-min incubation, each chamber was infused with DMEM containing monkey antimurine $\mathrm{GH}$ antiserum in a 1:200 dilution and one of the following concentrations of GHRH: $0,0.01,0.03,0.1,0.3$, or $1.0 \mathrm{nM}$. After a $90-\mathrm{min}$ incubation in the presence of the antiserum and GHRH, hemolytic plaques were developed over 35 min by addition of guinea pig complement (no. CS 1250; Colorado Serum Co.) at a 1:25 dilution. The cells were then fixed with $1 \%(0.01)$ gluteraldehyde, refrigerated in a beaker of distilled water overnight, stained with methyl green pyronin, and permanently mounted with Permount (Fisher Scientific Co., Fair Lawn, NJ).

Each slide was analyzed with respect to the percentage of plaque-forming cells and the mean plaque area. The percentage of plaque-forming cells was determined by microscopic quantification with respect to nonplaque-forming cells in a total population of 500 cells per slide. Occasional polymorphonuclear leukocytes and lymphocytes were excluded based on their characteristic morphology. This procedure was facilitated by the use of methyl green pyronin, which stains only nucleated cells. A hemolytic plaque was defined by the presence of a clear zone of red blood cell hemolysis that was at least as wide as the diameter of the pituitary cell and completely surrounded it. Any pituitary cell with a hemolytic plaque was considered to be a somatotrope. The relative amount of $\mathrm{GH}$ secreted was evaluated using a Videoplan image analysis system (Carl Zeiss, Kontron, Munich, Germany), as described previously (25). For each slide, the mean area of 100 plaques was determined, and statistical analyses of differences between plaque areas in the control and nephrectomized (CRI) groups were determined using analysis of variance followed by $t$ test. All mean plaque areas are expressed as the mean \pm SEM.

\section{RESULTS}

Effects of $s \%$ nephrectomy on serum, growth, and food utilization. Table 1 presents the results of serum, growth, and food use measurements for the CRI and sham-operated groups. The serum urea nitrogen and creatinine concentrations were significantly elevated in the CRI group; growth in the CRI group, measured by length and weight gain over the 2 -wk period, was significantly impaired in the CRI group and both food intake and food efficiency were significantly lower for the CRI group. It was noted that the mean growth rate of the uremic rats was only $1.1 \pm 0.9 \mathrm{~g} / \mathrm{d}$ over the first $3 \mathrm{~d}$ postnephrectomy, compared with $4.5 \pm 0.8 \mathrm{~g} / \mathrm{d}$ during $\mathrm{d} 3$ to 14 . For the sham rats, the mean growth rates for the 0 - to 3 -d period and the 3- to 14-d period were $6.1 \pm 0.4$ and $8.2 \pm 0.3 \mathrm{~g} / \mathrm{d}$, respectively. This shows that the growth rate of the uremic rats declined dramatically during the first few days postnephrectomy and then increased but never reached that of the sham rats.

Number of pituitary cells and percentage of somatotropes. Typical hemolytic plaques for $\mathrm{GH}$-secreting pituitary cells treated with 0 and $1.0 \mathrm{nM} \mathrm{GHRH}$ concentrations are shown in Figure 1. Table 2 presents data regarding the number of anterior pituitary cells, the percentage of somatotropes, and the absolute number of somatotropes. The mean total number of cells of the CRI group was not significantly different from that of the sham group. The percentage of the total pituitary cells that were capable of secreting $\mathrm{GH}$ was not significantly different in either group. nor was the absolute number of somatotropes $(p>0.10)$.

Plaque areas. An illustration of the concentration-response relationships between GHRH and mean plaque area for the CRI and sham groups is presented in Figure 2. The relationships for both the CRI and sham groups are similar, and no significant difference in mean plaque area was noted at any of the GHRH concentrations.

\section{DISCUSSION}

Elevated serum $\mathrm{GH}$ concentrations have been associated with CRI (8-13). Interpretation of these data is difficult because of the typical pulsatile pattern of GH secretion. Also, the elevated serum concentration may be due in part to inadequate excretion, because the kidney is a major site for GH excretion (14). However, a prompt decrease in GH concentration upon somatostatin administration suggests that the elevated concentration is mainly due to increased GH secretion (12).

Altered hypothalamic-pituitary regulation of $\mathrm{GH}$ secretion in the uremic environment is also suggested by observed abnormal $\mathrm{GH}$ responses to various stimuli in patients with $\mathrm{CRI}$. This includes a paradoxical rise in $\mathrm{GH}$ upon glucose administration (8-11), a rise in $\mathrm{GH}$ after thyrotropin-releasing hormone administration $(15,16)$, and a lack of $\mathrm{GH}$ release with hypoglycemia (16). With regard to serum IGF-I concentration in uremia, no significant difference has been observed between uremic and control individuals when RIA is performed after removal of interfering proteins $(20,26)$. Somatomedin activity, as measured by incorporation of radiolabeled sodium sulfate into cartilage, has been shown to be decreased (27), perhaps due to circulating inhibitors (28) in the uremic state. It is possible that this decreased somatomedin bioactivity is responsible for increased $\mathrm{GH}$ release, because there is evidence that IGF-I exerts negative feedback control on both the hypothalamus and the pituitary gland (29).

In this current study, a $5 / 6$ nephrectomy was used to mimic the uremic environment in rats. As illustrated by the elevated serum urea nitrogen and creatinine levels (Table 1 ), the $5 / \%$ nephrectomy produced a moderate degree of renal insufficiency in these animals. This degree of renal insufficiency resulted in marked growth failure, reduced food intake, and lower food efficiency (Table 1).

Using the reverse hemolytic plaque assay technique described above, the ability of pituitary somatotropes to secrete $\mathrm{GH}$ in response to varying GHRH challenges was determined, and no difference in responsiveness was found between the nephrectomized and sham-operated groups. These findings compare favorably with our in vitro study of $\mathrm{GH}$ responsiveness in perifused pituitary cells under conditions of mild uremia (30). These results 
Table 1. Serum urea nitrogen (SUN), serum creatinine, weight gain, length gain, food intake, and food efficiency for $5 \%$ nephrectomized $(n=6)$ and sham-operated $(n=6)$ rats (mean $\pm S E M)$

\begin{tabular}{|c|c|c|c|c|c|c|}
\hline Rat group & $\begin{array}{c}\mathrm{SUN} \\
(\mathrm{mg} / \mathrm{dL})\end{array}$ & $\begin{array}{c}\text { Creatinine } \\
(\mathrm{mg} / \mathrm{dL})\end{array}$ & $\begin{array}{c}\text { Weight } \\
\text { gain } \\
\text { (g) }\end{array}$ & $\begin{array}{c}\text { Length } \\
\text { gain } \\
(\mathrm{cm})\end{array}$ & $\begin{array}{c}\text { Food intake } \\
(\mathrm{g})\end{array}$ & $\begin{array}{c}\text { Food efficiency } \\
\text { ( } \mathrm{g} \text { wt gain } / \mathrm{g} \text { food) }\end{array}$ \\
\hline $5 / 6$ Nephrectomy & $\begin{array}{c}60.7 \pm 8.3 \\
(21.7 \pm 3.0)^{*}\end{array}$ & $\begin{array}{c}1.1 \pm 0.08 \\
(97 \pm 7) \dagger\end{array}$ & $53.2 \pm 6.6$ & $3.6 \pm 0.2$ & $281.6 \pm 22.2$ & $0.19 \pm 0.01$ \\
\hline Sham & $\begin{array}{l}15.8 \pm 1.2 \\
(5.6 \pm 0.4)^{*}\end{array}$ & $\begin{array}{l}0.4 \pm 0.04 \\
(35 \pm 4) \dagger\end{array}$ & $108.2 \pm 3.0$ & $5.0 \pm 0.1$ & $442.8 \pm 24.2$ & $0.25 \pm 0.01$ \\
\hline$p$ value & $<0.0005$ & $<0.0005$ & $<0.0005$ & $<0.0005$ & $<0.0005$ & $<0.005$ \\
\hline
\end{tabular}

* Value in $\mathrm{mmol} / \mathrm{L}$.

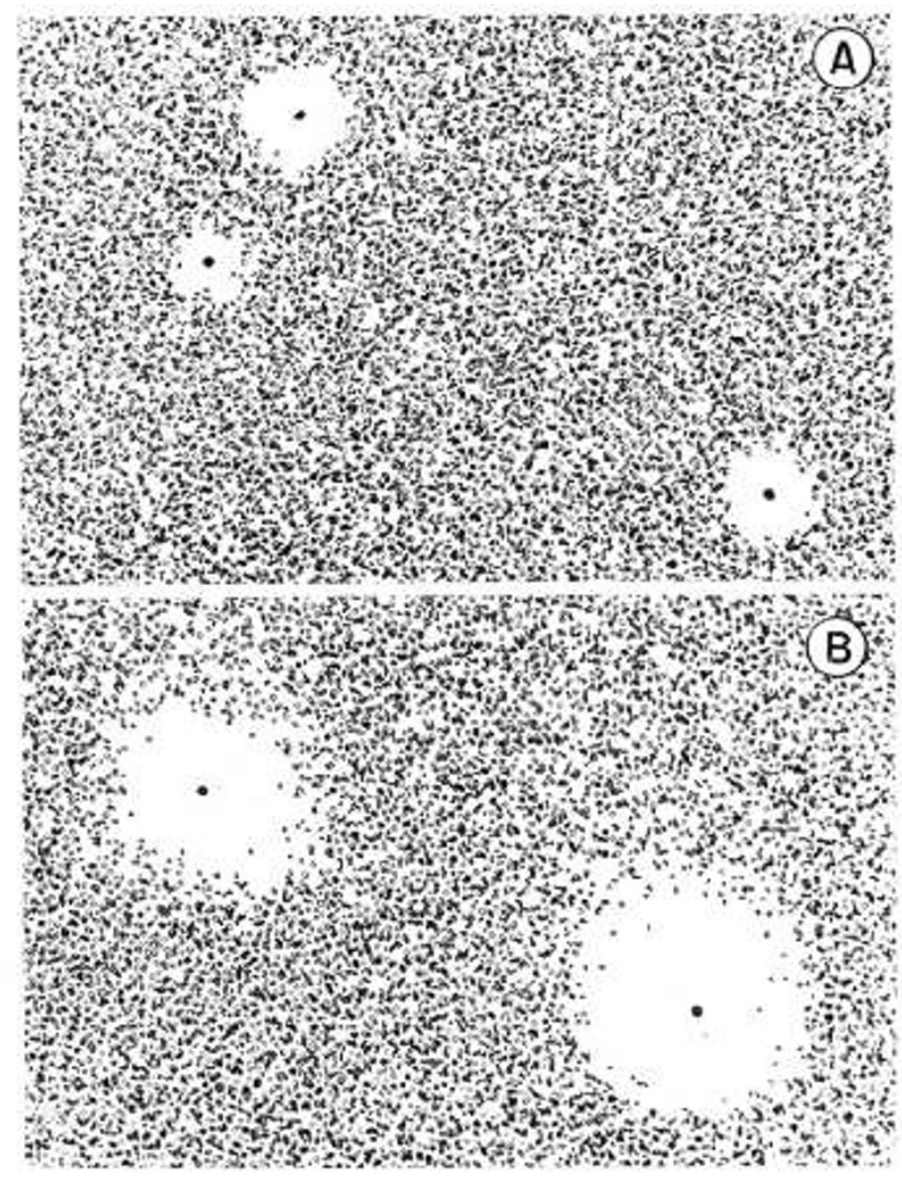

Fig. 1. Photomicrographs of plaques formed by rat pituitary cells using the reverse hemolytic plaque assay. $A$ shows typical plaques formed by cells without the addition of GHRH. $B$ shows typical plaques formed by cells treated with $1.0 \mathrm{nM} \mathrm{GHRH}$.

Table 2. Total number of pituitary cells, percentage of $\mathrm{GH}$ secreting cells, and absolute number of somatotropes for $5 \%$ nephrectomized $(n=6)$ and sham rats $(n=6)$ (mean $\pm S E M)$

\begin{tabular}{lccc}
\hline \multicolumn{1}{c}{ Rat group } & $\begin{array}{c}\text { Total number of } \\
\text { pituitary cells } \\
\text { (millions) }\end{array}$ & $\begin{array}{c}\% \mathrm{GH}- \\
\text { secreting } \\
\text { cells }\end{array}$ & $\begin{array}{c}\text { Absolute number } \\
\text { of somatotropes } \\
\text { (millions) }\end{array}$ \\
\hline \% $\%$ Nephrectomy & $3.5 \pm 0.6$ & $40.5 \pm 1.8$ & $1.45 \pm 0.29$ \\
Sham & $4.5 \pm 0.6$ & $38.6 \pm 0.5$ & $1.75 \pm 0.21$ \\
\hline
\end{tabular}

suggest that abnormal GH secretion observed in the CRI environment is due to something other than a change in somatotrope sensitivity to GHRH.

This experiment was designed to investigate $\mathrm{GH}$ secretion under conditions of sustained uremia. We noted that the growth rate dropped dramatically over the first $3 \mathrm{~d}$ after nephrectomy. The growth rate in the uremic rats increased after this initial

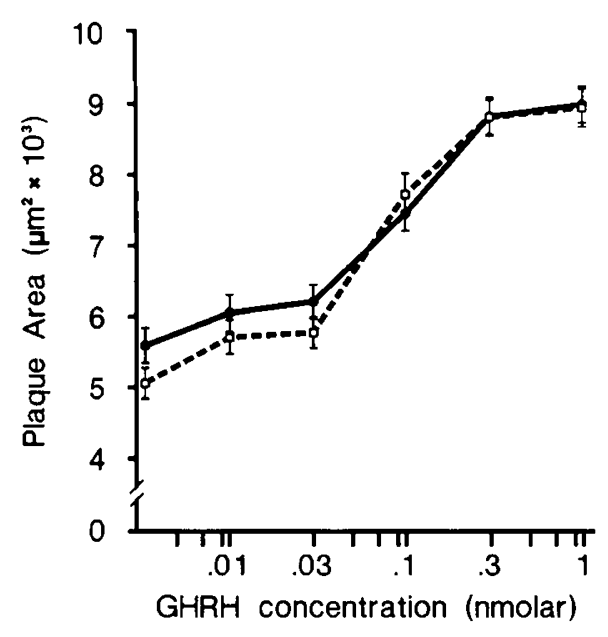

Fig. 2. GH secretory capacity of somatotropes at varying concentrations of GHRH for $\%$ nephrectomized (dotted line) and sham rats (solid line). Secretory capacity is expressed as mean plaque area \pm SEM in $\mu \mathrm{m}^{2}$. GHRH concentration ranged from 0 to $1.0 \mathrm{nM}$.

period, but not to that of the sham rats. Thus, this experiment does not rule out the possibility of a change in somatotrope secretory responsiveness under conditions of acute renal failure and severe growth rate impairment that occurs during the first few days after nephrectomy.

It should be noted that the current study was carried out in vitro and does not necessarily correspond to the in vivo uremic state. One concern is that any inhibitors or enhancers of $\mathrm{GH}$ secretion that could be present in uremic serum may have been washed away from somatotropes during the in vitro dispersion and incubation. Also, the food intake of the CRI rats was significantly lower than that of the control group, and this lower nutrition intake may affect $\mathrm{GH}$ regulation (31). Finally, many of the studies cited above that observed abnormal GH responses to various stimuli were carried out on human patients, and the rat model may not accurately correlate to those findings.

In conclusion, this study provides evidence that the $\mathrm{GH}$ secretory responsiveness of rat somatotropes is unchanged in a moderately uremic environment and that any abnormalities in $\mathrm{GH}$ regulation would be due to something other than altered responsiveness to GHRH.

\section{REFERENCES}

1. Henning P, Tomlinson L, Rigden SPA, Haycock GB, Chantler C 1988 Long term outcome of treatment of end stage renal failure. Arch Dis Child 63:3540

2. Foreman JW, Chan JCM 1988 Chronic renal failure in infants and children. J Pediatr 113:793-800

3. Chesney RW 1987 Growth retardation in childhood renal disease: a hormonal or nutritional problem? Am J Nephrol 7:253-256

4. Rizzoni G, Broyer M, Guest G, Fine R, Holliday MA 1986 Growth retardation in children with chronic renal disease: scope of the problem. Am J Kidney Dis 7:261-265

5. French CB, Genel M 1986 Pathophysiology of growth failure in chronic renal insufficiency. Kidney Int 30:S59-S64 
6. Mehls O, Ritz E, Gilli G, Kreusser W 1978 Growth in renal failure. Nephron $21: 237-247$

7. Chantler C, Holliday MA 1973 Growth in children with renal disease with particular reference to the effects of calorie malnutrition: a review. Clin Nephrol 1:230-242

8. Mehls O, Ritz E, Hunziker EB, Tonshoff B, Heinrich U 1988 Role of growth hormone in growth failure of uraemia: perspectives for application of recombinant growth hormone. Acta Paediatr Scand [Suppl] 343:118-126

9. El-Bishti MM, Counahan R, Bloom SR, Chantler C 1978 Hormonal and metabolic responses to intravenous glucose in children on regular hemodialysis. Am J Clin Nutr 31:1865-1869

10. Samaan NA, Freeman RM 1970 Growth hormone levels in severe renal failure. Metabolism 19:102-113

11. Wright AD, Lowy C, Fraser TR, Spitz IM, Rubenstein AH, Bersohn I 1968 Serum growth hormone and glucose intolerance in renal failure. Lancet 2:798-801

12. Pimstone BL, Le Roith D, Epstein S, Kronheim S 1975 Disappearance rates of plasma growth hormone after intravenous somatostatin in renal and liver disease. J Clin Endocrinol Metab 41:392-395

13. Mehls O, Ritz E, Hunziker EB, Eggli P, Heinrich U, Zapf J 1988 Improvemen of growth and food utilization by human recombinant growth hormone in uremia. Kidney Int 33:45-52

14. Johnson V, Maack T 1977 Renal extraction, filtration, absorption, and catabolism of growth hormone. Am J Physiol 233:F185-F196

15. Weissel M, Stummvoll HK, Kolbe H, Hofer R 1979 Basal and TRH-stimulated thyroid and pituitary hormones in various degrees of renal insufficiency. Acta Endocrinol 90:23-32

16. Ramirez G, O'Neill Jr WM, Bloomer HA, Jubiz W 1978 Abnormalities in the regulation of growth hormone in chronic renal failure. Arch Intern Med 138:267-271

17. Lacour B, Roullet JB, Bluet-Pajot MT, Yvert JP, Drueke T, Durand D 1986 Plasma and pituitary content of growth hormone luteinizing hormone, and prolactin in uremic rats. Nephron 44:235-239

18. Powell DR, Rosenfeld RG, Hintz RL 1988 Effects of growth hormone therapy and malnutrition on the growth of rats with renal failure. Pediatr Nephrol $2: 425-430$

19. Nakano M, Kainer G, Foreman JW, Ko D, Chan JCM 1989 The effects of exogenous rat growth hormone therapy on growth of uremic rats fed an $8 \%$ protein diet. Pediatr Res 26:204-207

20. Koch VH, Lippe BM, Nelson PA, Boechat MI, Sherman BM, Fine RN 1989 Accelerated growth after recombinant human growth hormone treatment of children with chronic renal failure. J Pediatr 115:365-371

21. Tonshoff B, Mehis O, Heinrich U, Blum WF, Ranke MB, Schauer A 1990 Growth-stimulating effects of recombinant human growth hormone in children with end-stage renal disease. J Pediatr 116:561-566

22. Rees L, Rigden SPA, Ward G, Preece MA 1990 Treatment of short stature in renal disease with recombinant human growth hormone. Arch Dis Child 65:856-860

23. Krieg Jr RJ, Johnson JH, Adler RA 1989 Growth hormone (GH) secretion in the pituitary-grafted male rat: in vivo effects of $\mathrm{GH}$-release in hormone and isoproterenol and in vitro release by individual somatotropes. Endocrinology 125:2273-2278

24. Cunningham AJ, Szenberg A 1968 Further improvements in the plaque technique for detecting single antibody-forming cells. Immunology 14:599600

25. Ho KY, Leong DA, Sinha YN, Johnson ML, Evans WS, Thorner MO 1986 Sex-related differences in $\mathrm{GH}$ secretion in rats using reverse hemolytic plaque assay. Am J Physiol 250:E650-E654

26. Powell DR, Rosenfeld RG, Sperry JB, Baker BK, Hintz RL 1987 Serum concentrations of insulin-like growth factor (IGF)-I, IGF-2 and unsaturated somatomedin carrier proteins in children with chronic renal failure. Am J Kidney Dis 10:287 292

27. Schwalbe SL, Betts PR, Rayner PHW, Rudd BT 1977 Somatomedin in growth disorders and chronic renal insufficiency in children. Br Med J 1:679-682

28. Phillips LS, Fusco AC, Unterman TG, DelGreco F 1984 Somatomedin inhibitor in uremia. J Clin Endocrinol Metab 59:764-772

29. Berelowitz M, Szabo M, Frohman LA, Firestone S, Chu L, Hintz RL 1981 Somatomedin- $C$ mediates growth hormone negative feedback by effects on both the hypothalamus and the pituitary. Science 212:1279-1281

30. Santos F, Chan JCM, Krieg RJ, Niimi K, Hanna JD, Wellons MD, Poletti LF 1992 Growth hormone secretion from pituitary cells in chronic renal insufficiency. Kidney Int 41:356-360

31. Soliman AT, Hassan AEHI, Aref MK, Hintz RL, Rosenfeld RG, Rogol AD 1986 Serum insulin-like growth factors I and II concentrations and growth hormone and insulin responses to arginine infusion in children with proteinenergy malnutrition before and after nutritional rehabilitation. Pediatr Res $20: 1122-1130$ 